http://journals.usm.ac.id/index.php/ijsp

\title{
TIPOLOGI EKOSISTEM INOVASI DAN KEWIRAUSAHAAN: POTENSI PRODUKTIVITAS INOVASI DI PROVINSI JAWA BARAT
}

\author{
Nabilla Dina Adharina \\ Institut Teknologi Nasional Bandung; Jalan PHH Mustapha No 23 Kota Bandung 40124; \\ adharinabil@itenas.ac.id
}

Info Artikel:

- Artikel Masuk: 01/12/21

- Artikel diterima: 29/12/21

- Tersedia Online: $31 / 12 / 21$

\begin{abstract}
ABSTRAK
Keterkaitan antara kewirausahaan dan produktivitas inovasi pada suatu daerah dengan pertumbuhan ekonomi telah mendorong banyak penelitian yang menunjukan bahwa inovasi dan kewirausahaan berkembang pada ekosistem tertentu. Dengan menggunakan analisis kluster, artikel ini membuat tipologi ekosistem inovasi dan kewirausahaan pada kabupaten dan kota di Provinsi Jawa Barat berdasarkan atribut-atribut yang mencerminkan produktivitas inovasi dan kewirausahaan, artikel ini menunjukan bahwa di Provinsi Jawa Barat hanya Kota Bandung yang memiliki ekosistem inovasi dan kewirausahaan yang baik jika dibandingkan dengan kota dan kabupaten lainnya. Selain itu, artikel ini mendapatkan bahwa aglomerasi perkotaan juga dapat menjadi penentu ekosistem inovasi dan kewirausahaan. Temuan dalam artikel ini dapat menjadi wawasan baru terutama dalam menyusun kebijakan terkait kewirausahaan dalam mendorong perekonomian baik lokal dan regional.

Kata Kunci : Ekosistem; Inovasi; Kewirausahaan; Tipologi
\end{abstract}

\section{ABSTRACT}

The association between entrepreneurship, innovation productivity with the economic growth has encouraged numerous researches showing that innovation and entrepreneurship are developed in the particular ecosystem. Using cluster analysis, this article created typology of the innovation and entrepreneurial ecosystem towards cities and regencies in West Java Province by employing attributes reflecting innovation productivity and entrepreneurship. This article found that only Bandung City which have a good innovation and entrepreneurial ecosystem compared to the other cities and regencies. Furthermore, this article also found that the urban agglomeration plays a role in determining the innovation and entrepreneurial ecosystem. These findings could be a new insight, particularly in creating better policy regarding entrepreneurship in order to foster both local and regional economic.

Keyword: Ecosystem; Entrepreneurship; Innovation; Typology

\section{PENDAHULUAN}

Berdasarkan berbagai penelitian yang pernah dilakukan sebelumnya (lihat Lee, 2013; Rahman \& Fatima, 2011), kewirausahaan ternyata memiliki peran penting dalam mendorong pertumbuhan kota. Di dalam kewirausahaan, Inovasi merupakan mesin utama yang mampu mendorong perkembangan kewirausahaan (Drucker, 1985; Rahman \& Fatima, 2011). Selain itu, Inovasi juga mencerminkan produktivitas dan salah satu ukuran yang dapat menjadi acuan mengenai perkembangan inovasi adalah akumulasi paten
(Griliches, 2007). Akumulasi paten menjadi cermin produktivitas dan perkembangan ekonomi suatu daerah terutama di negara maju, seperti Amerika (lihat (Kamyab, 2014; Mulligan, 2020). Paten merupakan bentuk penghargaan terhadap pencapaian yang telah didapatkan oleh wirausaha sehingga jumlah paten mencerminkan keberadaan wirausaha, produktivitas inovasi, dan keahlian sebagaimana ditemukan di area metropolitan seperti New York dan Los Angeles (Mulligan, 2020).

Perkembangan kewirausahan dan inovasi di negara maju berbeda dengan negara 
berkembang (Balunywa, 2006). Belajar dari New York dan Los Angeles dimana paten mencerminkan inovasi yang dilakukan kewirausahaan. Di negara berkembang seperti Indonesia, Rosa, Kodithuwakku, \& Balunywa, (2008) mendapatkan bahwa kewirausahaan pada negara berkembang belum banyak didampingi oleh inovasi karena keputusan berwirausaha lebih didasari oleh kemiskinan dan keterbatasan kesempatan terhadap lapangan pekerjaan formal sehingga wirausaha menjadi salah satu alternatif upaya untuk bertahan hidup. Meskipun begitu, agar kewirausahaan dapat memberikan dampak terhadap ekonomi lokal dan regional, inovasi merupakan faktor utama yang perlu dikembangkan (Drucker, 1985).

Kini kewirausahaan menjadi bagian dari kebijakan pemerintah dalam mendorong pertumbuhan ekonomi baik lokal dan regional. Sebagaimana yang telah dilakukan oleh Pemerintah Provinsi Jawa Barat dengan membuat regulasi kewirausahaan yang bertujuan untuk mendorong kreatifitas dan inovasi terutama pada kalangan muda. Pemerintah Provinsi Jawa Barat merupakan salah satu pemerintah yang aktif dalam mendorong kewirausahaan melalui peningkatan ekosistem kewirausahaan. Meskipun begitu, kewirausahaan tidak berkembang dengan cara yang sama pada tempat yang berbeda. Benneworth (2004) berargumen bahwa kewirausahaan adalah hasil dari sosial dan buday sehingga dari pernyataan tersebut dapat mengindikasikan bahwa kewirausahaan yang berkembang di Provinsi Jawa Barat pasti tidak homogen. Ekosistem yang mendukung perkembangan kewirausahaan menjadi kunci utama keberhasilan perkembangan kewirausahaan dan inovasi. Selain itu juga ekosistem tersebut yang membedakan perkembangan inovasi dan kewirausahaan di satu tempat dengan tempat lainnya. Henderson \& Weiler (2010) dalam studinya menemukan bahwa perkembangan inovasi dan kewirausahaan membutuhkan karakteristik perkotaan sehingga tingkat urbanisasi dapat menjadi indikator dalam melihat ekosistem kewirausahaan dan inovasi. Inovasi membutuhkan infrastruktur perkotaan dan pada waktu yang sama mampu menarik sumber daya manusia dengan tingkat pendidikan tinggi dan keahlian yang tinggi.

Berdasarkan hal tersebut maka tujuan dari artikel ini adalah mengidentifikasi potensi ekosistem inovasi dan kewirausahaan di Provinsi Jawa Barat dengan membuat tipologi kabupaten dan kota berdasarkan faktor-faktor yang mencerminkan produktivitas inovasi dan kewirausahaan. Berdasarkan yang telah dibahas sebelumnya, akumulasi paten merupakan cerminan dari produktivitas inovasi (Mulligan, 2020). Meskipun begitu, di negara berkembang, seperti Indonesia, paten masih merupakan hal "mewah" mengingat wirausaha yang berkembang masih didasarkan kebutuhan (Rosa et al., 2008). Kardoyo, Handoyo, Triyono, \& Laksani (2011) dalam penelitiannya menemukan bahwa paten di Indonesia masih sangat rendah walaupun jumlah wirausaha cukup tinggi. Oleh karena itu, dibutuhkan pendekatan lain selain paten untuk memahami ekosistem kewirausahaan dan inovasi di Provinsi Jawa Barat. Paten merupakan salah satu hak kekayaan industri. Selain paten, terdapat merek dan desain sehingga akumulasi merek dan desain juga dapat menjadi faktor alternatif yang mencerminkan kewirausahaan dan produktivitas inovasi. Pengetahuan tersebut menjadi penting untuk didapatkan mengingat penelitian yang berkaitan dengan kewirausahaan dan produktivitas inovasi di negara berkembang seperti Indonesia dengan karakter yang sangat berbeda jauh dengan negara maju masih sangat terbatas. Temuan yang didapatkan dari artikel ini diharapkan mampu memberikan wawasan baru yang mampu menjadi pertimbangan dalam menyusun kebijakan terkait kewirausahaan yang mampu mendorong pertumbuhan ekonomi.

\section{METODE DAN DATA}

\subsection{Metode}

Untuk mengetahui potensi ekosistem inovasi dan kewirausahaan di Provinsi Jawa Barat, penelitian menggunakan pendekatan kuantitatif. Dalam membuat tipologi kabupaten dan kota Provinsi Jawa Barat, artikel ini menggunakan analisis kluster. Analisis kluster memiliki tujuan utama mengelompokkan $n$ objek berdasarkan kesamaan karakteristik dari $p$ atau atribut (Edwards \& Cavalli-Sforza, 1965). Metode pengelompokan yang digunakan dalam 
artikel ini adalah metode hierarki. Asumsi utama dalam analisis kluster adalah tidak terjadi multikolinieritas (Romesburg, 2004). Tahapan yang dilakukan untuk menghasilkan kluster dalam artikel ini adalah sebagai berikut: (1) identifikasi masalah dan tujuan yang akan dicapai (2) menentukan atribut atau variabel yang mencerminkan karakter kewirausahaan pada kabupaten/kota berdasarkan kajian literatur (3) melakukan standardisasi pada variabel yang dipilih berdasarkan kajian literatur (4) melakukan uji multikolinieritas terhadap variabel-variabel yang dipilih berdasarkan kajian literatur (5) analisis kluster dengan SPSS (6) validasi (7) profiling kluster-kluster yang terbentuk.

\subsection{Data}

Untuk melakukan analisis, data yang digunakan merupakan data dengan jenis ukuran kontinu atau bersifat interval-rasio. Dalam mengidentifikasi tipologi kota dan kabupaten di Provinsi Jawa Barat, $n$ merupakan kabupaten dan kota dengan jumlah dua puluh enam kabupaten dan kota yang terdiri dari tujuh belas kabupaten dan sembilan kota. Atribut atau $p$ yang dianalisis adalah variabel-variabel yang mampu mencerminkan perkembangan kewirausahaan dan dampak ekonomi dari kegiatan kewirausahaan pada kabupaten atau kota. Berdasarkan hal tersebut, maka variabelvariabel yang dipilih adalah jumlah usaha mikro, kecil, dan menengah (UMKM), jumlah merek yang terdaftar hak kekayaan intelektual (HKI), jumlah desain yang terdaftar hak kekayaan intelektual $(\mathrm{HKI})$, jumlah paten yang terdaftar hak kekayaan intelektual (HKI), serta pendapatan per kapita pada masing-masing kabupaten dan kota di Provinsi Jawa Barat. Seluruh data yang digunakan merupakan data sekunder. Variabel-variabel yang terpilih merupakan data tahun 2019. Pemilihan data tahun 2019 dilakukan untuk menghindari perubahan tren akibat pandemi Covid-19 yang menghantam keras perekonomian di berbagai wilayah.

\section{HASIL DAN PEMBAHASAN}

\subsection{Hasil Analisis Kluster}

Dalam analisis kluster, asumsi utama yang perlu terpenuhi sebelum membentuk kluster adalah memastikan bahwa tidak terjadi multikolinieritas. Berdasarkan hasil pengujian korelasi antar variabel atau atribut yang telah disebutkan sebelumnya, ternyata terdapat korelasi sangat signifikan antara variabel jumlah paten, jumlah desain, jumlah merek, serta jumlah pendapatan per kapita dengan nilai sig. 2 tailed kurang dari dua. Berdasarkan hal tersebut, maka terjadi multikolinieritas sehingga diperlukan upaya selanjutnya, yaitu mereduksi variabel dengan nilai korelasi tinggi berdasarkan berbagai pertimbangan. Variabel yang dipertahankan dalam menentukan kluster adalah variabel jumlah paten dan UMKM. Jumlah paten dianggap telah mencerminkan jumlah kemampuan wirausaha di kabupaten atau kota tersebut dalam menciptakan baik merek serta desain. Oleh karena itu, semakin banyak jumlah paten yang dihasilkan wirausaha di suatu daerah dapat mencerminkan juga banyaknya jumlah merek dan desain yang dihasilkan. Variabel pendapatan daerah juga direduksi mengingat paten juga mampu mencerminkan perekonomian suatu daerah (lihat Lee, 2013). Dengan menggunakan dua variabel, yaitu jumlah paten dan jumlah UMKM, asumsi bahwa tidak adanya multikolinieritas terpenuhi sebagaimana dilihat pada Tabel 1.

Tabel 1. Korelasi antar variabel (hasil analisis SPSS, 2021)

\begin{tabular}{|c|l|r|r|}
\hline \multicolumn{2}{|c|}{} & $\begin{array}{c}\text { Zscore } \\
\text { (Paten) }\end{array}$ & $\begin{array}{c}\text { Zscore } \\
\text { (UMKM) }\end{array}$ \\
\hline $\begin{array}{c}\text { Zscore } \\
\text { (Paten) }\end{array}$ & $\begin{array}{l}\text { Pearson } \\
\text { Correlation }\end{array}$ & 1 & .347 \\
\cline { 2 - 4 } & Sig. (2-tailed) & & .076 \\
\cline { 2 - 4 } & $\mathrm{N}$ & 27 & 27 \\
\hline $\begin{array}{c}\text { Zscore } \\
\text { (UMKM) }\end{array}$ & Pearson & .347 & 1 \\
\cline { 2 - 4 } & Correlation & .076 & \\
\cline { 2 - 4 } & Sig. (2-tailed) & $\mathrm{N}$ & 27 \\
\cline { 2 - 4 } & & & \\
\hline
\end{tabular}

Berdasarkan analisis kluster yang telah dilakukan terhadap kabupaten kota di Provinsi Jawa Barat menggunakan variabel paten dan jumlah UMKM, didapatkan empat tipologi (lihat Tabel 2) dengan anggota masing-masing kluster pertama beranggotakan empat belas kabupaten/kota, sepuluh kabupaten/kota pada klaster kedua, dua kabupaten pada klaster ketiga, dan hanya satu kota pada klaster terakhir. 
Tabel 2. Anggota Kluster (hasil analisis, 2021)

\begin{tabular}{|c|l|}
\hline Kluster & Anggota Kluster \\
\hline 1 & $\begin{array}{l}\text { Kab. Sukabumi, Kab. Cianjur, Kab. } \\
\text { Garut, Kab.Tasikmalaya, Kab. Ciamis, } \\
\text { Kab. Cirebon, Kab. Majalengka, Kab. } \\
\text { Indramayu, Kab. Subang, Kab. } \\
\text { Karawang, Kab. Bekasi, Kab. Bandung } \\
\text { Barat, Kota Depok, dan Kota Bekasi. }\end{array}$ \\
\hline 2 & $\begin{array}{l}\text { Kab. Kuningan, Kab. Sumedang, Kab. } \\
\text { Purwakarta, Kab. Pangandaran, Kota } \\
\text { Bogor, Kota Sukabumi, Kota Cirebon, } \\
\text { Kota Cimahi, Kota Tasikmalaya, dan } \\
\text { Kota Banjar }\end{array}$ \\
\hline 3 & $\begin{array}{l}\text { Kabupaten Bandung dan Kabupaten } \\
\text { Bogor. }\end{array}$ \\
\hline 4 & Kota Bandung \\
\hline
\end{tabular}

3.2. Tipologi Kabupaten dan Kota di Provinsi Jawa Barat berdasarkan Ekosistem Kewirausahaan dan Inovasi

Berdasarkan kluster yang dihasilkan, didapatkan bahwa kluster tiga dan kluster empat adalah kota dan kabupaten yang memiliki jumlah paten dan UMKM terbanyak dibandingkan dengan kluster lainnya. Kemudian, kluster satu memiliki jumlah UMKM yang lebih banyak dibandingkan dengan kluster dua namun samasama tidak memiliki paten. Meskipun dalam pembentukan kluster, jumlah merek dan desain tidak dianalisis untuk memenuhi asumsi multikolinieritas, dalam melakukan profiling kluster, pengetahuan mengenai seberapa banyak hak kekayaan industri lainnya seperti merek dan desain menjadi sangat penting. Sebagaimana dapat dilihat pada Gambar 1, rata-rata jumlah merek dan desain juga menunjukkan pola yang hampir serupa. Kluster tiga dan kluster empat memiliki rata-rata jumlah merek dan desain yang jauh lebih tinggi jika dibandingkan dengan kluster lainnya. Meskipun kluster dua memiliki jumlah rata-rata UMKM yang lebih sedikit dibandingkan dengan kluster satu, ternyata rata-rata jumlah merek dan desain kluster dua lebih tinggi. Dengan mempertimbangkan inovasi sebagai karakter utama kewirausahaan (Drucker, 1985), kluster dua lebih mencerminkan ekosistem yang lebih baik untuk inovasi dan kewirausahaan karena kekayaan industri merupakan indikator penting yang merefleksikan karakter utama wirausaha yaitu adanya motivasi untuk mendapatkan suatu pencapaian dan adanya kreatifitas (Kusmintarti, Thoyib, Ashar, \& Maskie, 2014). Kondisi ini dapat mengindikasikan bahwa wirausaha yang dicerminkan dengan jumlah UMKM pada kluster satu belum menunjukan orientasi kewirausahaan terhadap inovasi mengingat jumlah merek dan desain yang masih rendah jika dibandingkan dengan kluster lainnya.

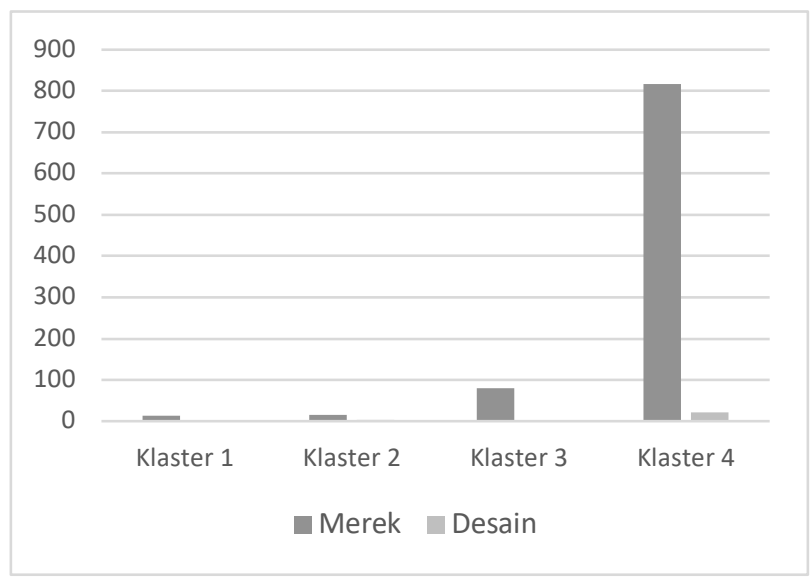

Gambar 1. Grafik perbandingan rata-rata jumlah kekayaan industri merek dan desain (hasil analisis, 2021)

Berdasarkan empat kluster yang dihasilkan dan profiling yang dilakukan terhadap masing-masing kluster, berikut merupakan tipologi ekosistem dan kewirausahaan pada setiap kluster yang dibagi menjadi ekosistem inovasi dan kewirausahaan yang kurang, sangat kurang, cukup, dan baik:

1. Kluster satu memiliki ekosistem yang sangat kurang karena memiliki rata-rata jumlah UMKM dan jumlah HKI jauh di bawah ratarata jumlah di Provinsi Jawa Barat.

2. Kluster dua memiliki ekosistem yang kurang jika dibandingkan dengan kluster satu namun tetap memiliki rata-rata jumlah UMKM dan jumlah HKI di bawah rata-rata jumlah Provinsi Jawa Barat.

3. Kluster tiga memiliki ekosistem kewirausahaan yang cukup jika dibandingkan dengan kluster satu dan kluster dua karena memiliki rata-rata jumlah UMKM jumlah HKI di atas rata-rata jumlah Provinsi Jawa Barat.

4. Kluster satu memiliki ekosistem yang baik jika dibandingkan dengan tiga kluster lainnya karena memiliki jumlah UMKM dan HKI jauh di atas rata-rata jumlah Provinsi Jawa Barat.

Dengan melihat persebaran secara geografis anggota masing-masing kluster sebagaimana ditunjukkan pada Gambar 2, Kota 
Bandung (kluster satu), Kabupaten Bandung dan Kabupaten Bogor (kluster dua) merupakan bagian dari dua kawasan metropolitan yaitu Kawasan Cekungan Bandung dan Kawasan Metropolitan Jabodetabek-Punjur. Kondisi ini mendukung pernyataan Henderson \& Weiler (2010) bahwa perkembangan inovasi dan kewirausahaan membutuhkan karakteristik perkotaan. Mengingat dua kabupaten ini merupakan bagian dari aglomerasi perkotaan yang besar, dua kabupaten ini mendapatkan banyak manfaat dari aglomerasi tersebut baik secara fisik infrastruktur dan non-fisik. Adharina \& Seruni, (2021) dalam penelitiannya mendapatkan bahwa kedekatan juga dapat memberikan manfaat transfer pengetahuan yang mendorong inovasi terjadi. Oleh karena itu, kota-kota besar dengan ekosistem inovasi dan kewirausahaan yang baik seperti Kota Bandung dan Jakarta mampu menjadi pusat yang dapat menyebarkan manfaat tersebut ke daerah yang ada di sekitarnya. Selain itu, pada Gambar 2 juga dapat dilihat bahwa secara keseluruhan ekosistem inovasi dan kewirausahaan di Provinsi Jawa Barat masih didominasi oleh tipe ekosistem yang sangat kurang dan kurang. Ekosistem yang baik masih didominasi oleh bagian dari kawasan perkotaan sebagaimana telah disampaikan.

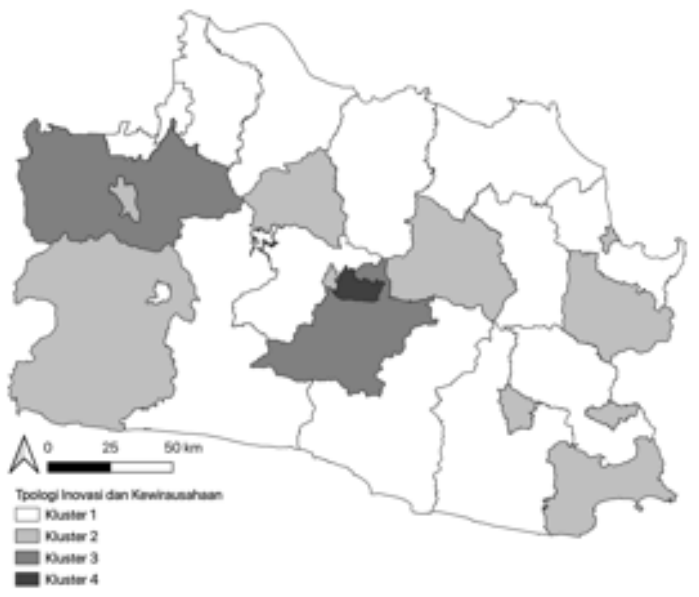

Gambar 2. Tipologi Ekosistem Inovasi dan Kewirausahaan dan Provinsi Jawa Barat (hasil analisis, 2021)

\section{SIMPULAN}

Hasil analisis dan temuan dalam artikel ini menekankan bahwa ekosistem inovasi dan kewirausahaan di Provinsi Jawa Barat masih cenderung terpusat di Kota Bandung sebagai
Ibu Kota Provinsi Jawa Barat. Dengan melihat kluster yang terbentuk serta jumlah kekayaan industri lainnya seperti desain dan merek, dapat dikatakan bahwa hanya Kota Bandung yang memiliki ekosistem kewirausahaan dan inovasi yang sangat baik jika dibandingkan dengan kabupaten dan kota lainnya di Provinsi Jawa Barat. Meskipun begitu, Kabupaten Bogor (bagian dari kawasan metropolitan Jabodetabek-Punjur) dan Kabupaten Bandung (bagian dari kawasan metropolitan Cekungan Bandung) memiliki ekosistem yang cukup jika dibandingkan dengan kabupaten dan kota lainnya di Provinsi Jawa Barat. Situasi ini menekankan peran aglomerasi perkotaan terhadap manfaat transfer pengetahuan terhadap kawasan di sekitarnya memiliki peran yang penting (Adharina \& Seruni, 2021; Henderson \& Weiler, 2010). Untuk memperkuat temuan ini di dalam konteks Provinsi Jawa Barat, penelitian-penelitian terkait pengaruh faktor-faktor tingkat urbanisasi dan kemampuan inovasi suatu daerah dapat menjadi tindak lanjut yang penting untuk dapat mempelajari sejauh apa ekosistem inovasi dan kewirausahaan di Provinsi Jawa Barat berkembang dan mampu mendorong pertumbuhan ekonomi baik lokal dan regional.

\section{REFERENSI}

Adharina, N. D., \& Seruni, P. (2021). BAGAIMANA INOVASI GAGAL: PEMBELAJARAN DARI KLASTER INDUSTRI SARUNG MAJALAYA. Indonesian Journal of Spatial Planning, 1(2), 29-36.

Balunywa, W. (2006). Reassessing Necessity Entrepreneurship in Developing Countries.

Benneworth, P. (2004). In what sense 'regional development?': Entrepreneurship, underdevelopment and strong tradition in the periphery. Entrepreneurship \& Regional Development, 16(6), 439-458.

Drucker, P. F. (1985). Innovation and entrepreneurship practices and principles. Amacon.

Edwards, A. W., \& Cavalli-Sforza, L. L. (1965). A method for cluster analysis. Biometrics, 362-375.

Griliches, Z. (2007). R\&D, patents and productivity. University of Chicago Press. 
Henderson, J., \& Weiler, S. (2010). Entrepreneurs and job growth: Probing the boundaries of time and space. Economic Development Quarterly, 24(1), 23-32.

Kamyab, S. H. (2014). The entrepreneurship, knowledge spillover and economic growth. International Journal of Sustainable Development \& World Policy, 3(2), 45-54.

Kardoyo, H., Handoyo, S., Triyono, B., \& Laksani, C. S. (2011). Kebijakan Paten dalam mendorong aktivitas inovasi di Indonesia. Jakarta: LIPI Press.

Kusmintarti, A., Thoyib, A., Ashar, K., \& Maskie, G. (2014). The relationships among entrepreneurial characteristics, entrepreneurial attitude, and entrepreneurial intention. IOSR Journal of Business and Management, 16(6), 25-32.

Lee, Y. S. (2013). Entrepreneurship, small business, and urban growth. Unpublished Working Paper, Williams College.

Mulligan, G. F. (2020). Revisiting patent generation in US metropolitan areas: 1990-2015. Applied Spatial Analysis and Policy, 1-24.

Rahman, M., \& Fatima, N. (2011). Entrepreneurship and urban growth: Dimensions and empirical models. Journal of Small Business and Enterprise Development.

Romesburg, C. (2004). Cluster analysis for researchers. Lulu. com.

Rosa, P., Kodithuwakku, S., \& Balunywa, W. (2008). Entrepreneurial Motivation in Developing Countries: What does' Necessity'and'Opportunity'Entrepreneur ship Really Mean? Babson College Entrepreneurship Research Conference (BCERC) 2006 Paper. Presented at the Frontiers of Entrepreneurship Research 2006. 